Article

\title{
Tourist Satisfaction, Willingness to Revisit and Recommend, and Mountain Kangyang Tourism Spots Sustainability: A Structural Equation Modelling Approach
}

\author{
Liyun Zeng ${ }^{1,2, *(\mathbb{D})}$ and Rita Yi Man $\mathrm{Li}^{3}(\mathbb{D}$ \\ 1 Rattanakosin International College of Creative Entrepreneurship, Rajamangala University of Technology \\ Rattanakosin, Bangkok 10700, Thailand \\ 2 Civil and Architectural Engineering Institute, Panzhihua University, Panzhihua 617000, China \\ 3 Sustainable Real Estate Research Center, Hong Kong Shue Yan University, Hong Kong 999077, China; \\ ymli@hksyu.edu \\ * Correspondence: nonsar@foxmail.com; Tel.: +86-156-0091-2550
}

Citation: Zeng, L.; Yi Man Li, R. Tourist Satisfaction, Willingness to Revisit and Recommend, and Mountain Kangyang Tourism Spots Sustainability: A Structural Equation Modelling Approach. Sustainability 2021, 13, 10620. https://doi.org/ $10.3390 /$ su131910620

Academic Editor: Alan Fyall

Received: 15 August 2021

Accepted: 21 September 2021

Published: 24 September 2021

Publisher's Note: MDPI stays neutral with regard to jurisdictional claims in published maps and institutional affiliations.

Copyright: (C) 2021 by the authors. Licensee MDPI, Basel, Switzerland. This article is an open access article distributed under the terms and conditions of the Creative Commons Attribution (CC BY) license (https:// creativecommons.org/licenses/by/ $4.0 /)$.
Abstract: The rapid development of society and economy has imposed insurmountable pressure on the urban population, and many people suffer from sub-health conditions. Kangyang tourism (KT), which combines the concepts of health preservation, ecological resources, and tourism activities, has developed rapidly in China since the concept was first introduced. Although previous studies have examined the relationship among experience, satisfaction, and intention, there is a lack of study of experience value's impact on Mountain Kangyang Tourim Spots' Sustainability, that is, willingness to revisit and recommend to other potential tourists. Consequently, an "experience value (functional value, contextual value, emotional value, cognitive value, economic value), satisfaction and post-trip willingness to revisit and recommend" framework is suggested to examine mountain Kangyang tourism (MKT). Data were collected from 500 tourists after visiting five well-known MKT destinations in Panzhihua city. Using the structural equation modeling (SEM) technique, the results suggest that tourist satisfaction plays an important role in experience value as well as willingness to revisit and recommend the MKT spots after their revisits. Our research offers some practical suggestions for MKT destination operators when they design and provide MKT destinations. The results would be useful for governments and non-profit organizations which attempt to promote MKT.

Keywords: mountain Kangyang tourism; structural equation model; experiential value; satisfaction; post-trip intention

\section{Introduction}

\subsection{Lifestyle and Health Trends in Global Demographics}

In recent decades, non-communicable diseases (such as heart disease and cancer) have been the leading cause of death. These may be caused by bad habits or inappropriate lifestyles [1]. People live in urban areas usually suffer stress from fast-paced life and work [2] and adverse environmental conditions, which affect their physical health and mental state $[2,3]$. Thus, there is an increasing need to stay away from sources of stress at workplace, school, and other living scenarios [3]. Likewise, COVID-19 has brought substantially unprecedented social and economic problems [4]. According to the United Nations World Tourism Organization (UNWTO), tourism will not return to the pre-COVID19 state for another two or three years, and recovery after COVID-19 must respond to the crisis and underpin tourism recovery in the long run $[5,6]$. People increasingly need to be close to nature to heal their bodies and minds when facing such a global crisis [7].

\subsection{The Emergence of Global Health Tourism}

The WTO published documents to promote "health and well-being" tourism as a Sustainable Development Goal (SDG) by 2030. The goal is to promote the health and 
well-being of local communities, tourists, and tourism staff [8]. Thus, many travel agencies provide nature-based tours for those who need mental refreshment [9]. The idea of traveling for physical, mental, or spiritual rejuvenation appeals to travelers, especially those cramped with family and work responsibilities [3]. Increasingly, consumers travel during vacation for health and wellness [3]. Health-oriented tourism, such as health tourism, medical tourism, and wellness tourism, has emerged as one of the fastest-growing tourism worldwide [9].

\subsection{Kangyang Tourism in China}

China is facing the challenges of a growing aging population and severe pollution. These problems, however, make wellness tourism more attractive [10]. This type of travel provides a healthy lifestyle for tourists to promote their physical, mental, and spiritual health through traveling. Firstly, the developmental level of wellness tourism varies from country, depending on socioeconomic conditions and availability of natural and cultural resources [2,11]. In China, natural bath, self-cultivation, taijiquan, wushu, traditional medicine, massage, medicinal herbs, or even living in a "longevity village" can be considered as wellness activities from the perspective of Chinese wellness culture [11]. Gradually, Kangyang tourism has formed as a kind of wellness tourism in China, which also incorporates other activities such as health and fitness, nutritious diet, spiritual cultivation, mental training, environmental conservation. Kangyang participants can achieve physical, mental and spiritual harmony (Standard for National Health and Wellness Tourism Demonstration Base, 2020). Kangyang tourism was developed with the support of Chinese policies and relevant governments in China. According to the Government of the People's Republic of China (http: / / www.gov.cn, accessed on 10 August 2020) and Ministry of Cultural and Tourism of the People's Republic of China (https:/ / www.mct.gov.cn, accessed on 10 August 2020), there are several policies, such as Outline of the 30-year Plan for Healthy China (2016), and Standard for National Health and Wellness Tourism Demonstration Base (2020). Kangyang tourism industry can benefit the economic, cultural, and social development in the country, especially in the post-COVID-19 period.

In addition, there are numerous mountain resources with green and blue spaces [12] in China. After the implementation of Kangyang tourism in China, the rapid development of mountain-based Kangyang tourism (MKT) has been promoted, significantly influences the development of tourism. In the development of MKT, opinions from tourists and effective communication channels are required for infrastructure construction [13], landscape management [14], and tourism product development [15].

\subsection{Research Question and Structure}

This paper mainly studies Kangyang tourism from the perspective of tourists. The paper aims to explore the relationship among the MKT tourists' experiential value (functional value, contextual value, emotional value, cognitive value and economic value), satisfaction, willingness to revisit and recommend after their visits. The novelty of the study is the use of SEM to assess the relationship among the experiential value, satisfaction, and intention of tourists visiting MKT sites in China. A better understanding of these relationships can help MKT destination providers to plan and design better Kangyang tourism spots for visitors, assist governments and non-profit organizations in promoting MKT. Tourists' post trip behaviours, that is, willingness to revisit and recommend the MKT spots affect MKT sustainability in the long run. The research questions of this paper are as follows:

(1) What factors can enhance the satisfaction of the MKT tourists' experiences?

(2) What factors can enhance the willingness of the MKT tourists to revisit and recommend?

(3) What is the relationship between the MKT tourists' satisfaction, experience, and willingness to revisit and recommend?

The rest of this paper is structured as follows: Section 2 presents the conceptual background and hypotheses development about MKT; Section 3 describes the research areas and methods; Section 4 describes the data collection and analysis; Section 5 shows the 
results and findings; Section 6 is the discussion part; Section 7 is the conclusion constructed by theoretical contributions and managerial implications; the last Section 8 is limitations.

\section{Concepts and Hypotheses Development}

\subsection{Health Tourism and Wellness Tourism}

Health tourism is a comprehensive concept. It is based on natural resources: mineral water, therapeutic mud, and climatic conditions, which complement each other and enhance the treatment effect of various diseases [16]. Heath tourism encompasses medical [17], wellness [18], and spa tourism [18]. Heath tourism concerns psychological, physical, and social factors, and the concept of wellness (the optimal state of health), resulting in a more positive definition of health [19]. Sometimes, "health" tourism is different from "wellness" tourism. Health tourism emphasizes more on medical-related activities such as cardio or cosmetic surgery. Wellness tourism represents a more holistic approach where a traveler seeks general well-being enhancement through participating in activities such as yoga, Tai chi, hot spring/spa, massage, and physical activities [3].

Wellness tourism can be broadly defined as a physical activity undertaken by tourists to improve their health. Generally, these activities incorporate physical fitness/beauty care, healthy nutrition/diet, relaxation/meditation, and mental activity/education [20]. Wellness tourism is called the main type of tourism [2]. Many marketing channels promote wellness tourism as a form of tourism activity that satisfies the well-being of people, represents an effective lifestyle and behavioral change [21]. Wellness tourism is relevant to many aspects of life, such as health, social, and economic well-being [22]. Wellness tourism is related to a more complex paradigm of wellness research that balances the human mind, spirit, body, environment, and quality of life [23,24]. It is an all-encompassing term that involves traveling to the regions with the most favorable natural conditions, including climate for health and the prevention, treatment, or rehabilitation of disease [16].

\subsection{Mountain-Based Kangyang Tourism (MKT)}

As a new concept applicable worldwide, Kangyang tourism is integrated with various cultural and historical elements [25]. Wellness tourism has different meanings in different languages and cultures [11], and it is known as Kangyang tourism in China. Concerning cultural perspectives on health tourism, few papers addressed the role of cultural and natural characteristics of destinations in health tourism. As mentioned above, some researchers pointed out that future studies should focus on mountains because specific locations and traditional Chinese culture characterized by a particular microclimate contribute to longevity and health, etc. [26].

Mountain-based Kangyang tourism is a kind of Kangyang tourism in mountain areas. Most of the relevant studies were based on geographic or cultural contexts. Christina and Andreas (2011) focused on climate change affecting human health and recreation in the mountainous regions of southwestern Germany [27]. Cheng, Li, Zhang et al. (2017) explored the cultural, psychological, ideological impacts of Taoism on tourists of wellness tourism in the Wudang Mountains of China [25]. Yang (2017) aimed at the development of wellness tourism resources for Chang-Ji-Tu regions [28]. Bae and Lee (2019) verified the influence of place attachment recognition on tourist satisfaction and future behavioral intention in mountain villages [29]. Pan, Yang, and et al. (2019) analyzed how the potential areas at seven counties (Horgos, Huocheng, Qapqal, Zhaosu, Tekes, Tokkuztara, and Narat) in Xinjiang, China [11] make full use of their strengths to cater to different MKT activities. Yong (2020) studied the significance of landscape plans on improving the quality of life in rural mountainous areas [30]. Choi and Kim (2021) concluded that tourism attributes could positively impact tourist satisfaction, and satisfaction can do the same thing on the intention to revisit Sokcho City with mountain tourism resources and so on [31]. 


\subsection{Experience Value, Satisfaction, and Revisit Intentions}

In various tourism research, some researchers studied the effect of satisfaction on reparticipation/revisit intention in the context of sports tourism many years ago [32], cultural tourism festivals [33], etc., such as Cheol-Woo, Lee (2004) and Junghoon (2005). Except for the tourist satisfaction and intention, Yong-ho (2006) and Joo (2008) started to focus on tourist experience and examined service quality of village tourism [34] and medical tourism [35]. In terms of adventure tourism, Paul and Geoffrey N. (2009) researched the significance of value on satisfaction and behavioral intentions and conceptualized values as value for money, emotional value, and novelty value [36]. The structural research of experience/perception (value), satisfaction, and behavior intentions are becoming an increasing tendency in terms of ecotourism and leisure tourism $[37,38]$.

Mostafa, Siamak, Ahmad and et al. (2021) investigated the mediating role of tourist satisfaction in the relationship between memorable tourism experiences and behavioral intentions in heritage tourism [39]. Rahman, Sabbir, Surajit and et al. (2021) aimed to investigate tourist willingness to conduct a medical tourism revisiting and suggested that stakeholders should focus on the hedonic/emotional and utilitarian/functional, and economic factors of the destination [40]. Some researchers, such as Seokho, Yoon, Ji-Hwan, and Jookyung (2021), investigated how the multidimensional components of AR experiential value (i.e., visual appeal, entertainment, enjoyment, and escapism) affect supportive behavior through AR satisfaction [41].

In the current context of sports tourism, Anne-Marie, Che-Jen, and Patrick (2021) constructed a framework of consumer experience-satisfaction-behavioral intentions, and highlighted that the experiential context could distinct the actual visitor experience in each park in terms of education cognitive, contextual esthetics, emotional entertainment, escapism, and functionally physical activity [42]. Thus, though many researchers have analyzed the relationship among satisfaction, experience, and behavioral intentions in tourism, few researchers studied this topic in the context of MKT, especially the dimensions of experiential value. As mentioned above, the novelty of this paper is mainly on the "experience value-satisfaction-behavior intentions" framework construction in MKT. Understanding these concepts and definitions is essential in the paper.

\subsubsection{Experiential Value}

Experiential value can be considered a subjective construction that varies from consumers, destinations, and cultures over time [43]. In other words, tourists evaluate tourism destinations based on the benefits acquired [43]. As a conceptual framework, experiential value refers to feelings and attitudes that attract consumers to purchase certain products in a competitive environment [44,45]. Based on the definitions and conclusions of previous research, this study defines "experience value" in MKT as the feelings and evaluation of consumers when using the facilities and services in MKT. Experiential value can be classified into five types: functional [46], contextual [43,46], cognitive [47,48], emotional [44-46], and economic values $[49,50]$.

\section{(1) Functional Value}

Functional value is a basic experiential value [51]. Functional value refers to the perception and evaluation of basic tourism functions such as transportation, safety, environment, tourist routes, and supporting facilities [52]. In terms of mountain Kangyang tourism, functional value indicators include transportation convenience [11], planning and design rationality [14], service quality and efficiency $[46,53]$, supporting facilities $[11,16]$, public order and safety $[17,54]$, medical personnel $[11,55]$, and environmental protection $[3,56]$.

\section{(2) Contextual Value}

Contextual value of tourism refers to the perception and evaluation from visitors of environmental atmosphere and service attitudes of recreational areas $[57,58]$. The contextual value indicators include reputation [1,59,60], landscape environment [14], veg- 
etation coverage [12,15,26], architectural characteristics [13], service attitude [61], and climatic conditions [26].

(3) Emotional Value

Emotional value refers to the ability and utility of a product that can change the emotional state of consumers [62]. The emotional value of tourism refers to the emotions of tourists after travel and the perceptual utility that stimulates the emotional state of the individual. A higher perceptual level means a more satisfying emotional need for pleasure and aesthetics so that tourists can obtain positive emotional value $[52,63,64]$. The emotional value indicators include relaxation and excitement [11,65], travel freshness [9], comfort [66], the pleasure of knowledge and stories [67], leisure and fitness of group activities [22], and happiness of communication [26].

\section{(4) Cognitive Value}

Cognitive value refers to the attribute that can satisfy the pursuit of knowledge of customers $[68,69]$. The cognitive value of tourism refers to gain knowledge, skills, and horizons in recreational experience $[52,68]$. The cognitive value indicators include knowledge acquisition [17], the experience of local cultures [3,26], and participation in competitions [17].

\section{(5) Economic Value}

Economic value refers to the return on investment for consumption [62]. The economic value of tourism refers to the perception and evaluation of travel expenses from tourists [52]. The economic value indicators include reasonable price [43], value for money [46,56,70,71], and time-saving and labor-saving [11] in mountain Kangyang tourism.

\section{(6) Interrelationship of Experiential Value}

In terms of medical tourism, rural tourism, adventure tourism, and sports tourism, functional value and/or contextual value positively impact emotional, economic, and cognitive value $[34,35,40,42]$. The correlation among the above keywords was usually found in the product market [46]. The functional value and contextual value in the tourism experience are the basis of the other three values. On the one hand, only with reasonable planning and design, convenient traffic conditions, appropriate supporting facilities, service efficiency, safety, etc. (functional value) in tourist destinations, tourists shall have positive emotions (such as happiness, excitement, relaxation), gain new knowledge to create cognitive value, and then feel the tourist spot good value for money because of the low cost of travel time, traffic fee, etc.

Thus, the following hypotheses are proposed:

H1a. Functional value (F1) has a direct impact on emotional value (F3) in MKT.

H1b. Functional value (F1) has a direct impact on economic value (F5) in MKT.

H1c. Functional value (F1) has a direct impact on cognitive value (F4) in MKT.

On the other hand, when the environment and services attitudes and other aspects (conceptual value) are guaranteed, tourists can feel psychologically comfortable spending more time and money in the tourism destination, and can get more chances to learn about the local cultural knowledge. Furthermore, a reasonable spending experience can make tourists feel good value for money, generating economic value.

Thus, the following hypotheses are proposed:

H2a. Contextual value (F2) has a direct influence on emotional value (F3) in MKT.

H2b. Contextual value (F2) has a direct influence on economic value (F5) in MKT.

H2c. Contextual value (F2) has a direct influence on cognitive value (F4) in MKT. 


\subsubsection{Satisfaction}

Satisfaction refers to the degree to which travel expectations and actual experiences are satisfied [72]. Professional management of a destination is necessary to optimize the satisfaction and experiential value of visitors [43]. Tourists who have a positive travel experience, a good image, and/or are highly satisfied after visiting tourism destinations may wish to revisit or recommend the destination [38]. When people are satisfied and happy, well-being means the needs of the individual are fulfilled, thus contributing to the community [70]. Therefore, it is necessary to analyze the satisfaction of tourists in MKT.

\subsubsection{Behavior Intentions}

Behavior intention includes the willingness to revisit and recommend [73]. These studies have explored the outcomes of the experience of the visitor and tested the relationship among experience and value [46], behavior intention [74], intention to recommend [75], revisiting [76], perceived value [77], and the satisfaction of visitors [78]. Historically, satisfaction has been regarded as the most well-known variable predicting the intention of re-visitation [79-81].

\subsubsection{Experiential Value and Satisfaction}

Bajs (2015) revealed a direct effect of experience on satisfaction in leisure tourism [82]. Visitor satisfaction encompasses the accumulated experiences (such as context, emotion, and cognitive) of tourism service consumption [43]. People conduct MKT to avoid the hustle and bustle of the city, change their environment, enjoy leisure time, cultivate the body and mind, and so on. Therefore, the destination popularity and landscape uniqueness in context may not be the most important factors. On the contrary, the friendly service attitude, laid-back and relaxed atmosphere and creative-knowledgeable themes are more important. Thus, the contextual, emotional and cognitive value may have a great impact on tourist satisfaction.

Accordingly, the following hypotheses are proposed:

H3a. Contextual value (F2) directly influences tourist satisfaction (F6) in MKT.

H3b. Emotional value (F3) directly influences tourist satisfaction (F6) in MKT.

H3c. Cognitive value (F4) directly influences tourist satisfaction (F6) in MKT.

In an adventure tourism context, the direct significance of economic value on satisfaction is verified by Paul and Geoffrey N. (2009) [36]. People's main consumer psychology for MKT is to enjoy the happiness of relaxation during the limited vacation. They hope that the MKT destinations will be accessible and reasonably priced [29]. If the experience is economical and value-for-money, tourist satisfaction will naturally be high; mountain health tourism destinations also have high-end holiday tourism products, although the consumer price is high; if the cost of travel time and energy is higher than that of other tourist destinations of the same type, tourists will enjoy the same quality of vacation fun but with higher satisfaction $[53,54]$, which is also MKT destinations should strive to boast compared to long-distance tourism vacations.

Accordingly, this article proposes the following hypotheses:

H3d. Economic value (F5) directly influence tourist satisfaction (F6) in MKT.

\subsubsection{Satisfaction and Behavior Intention}

Historically, tourism and destination management studies have considered satisfaction as one of the most important variables given that it allows tourists to show positive postvisit behavioral outcomes, such as re-visitation or recommendation ("word-of-mouth" effect) [83]. Hence, various key determinants have been examined to understand how to satisfy tourists [84]. This study considers tourist satisfaction an important intermediary variable for studying the relationship between experience value and behavior intention. 
Thus, the following hypotheses are proposed:

H4. Visitor satisfaction (F6) directly influences behavior intention (F7) in MKT.

\section{Research Areas and Methods}

\subsection{A Study Location}

Panzhihua City is located in Sichuan Province, the southwest of China. As a remote MKT destination containing different ethnic resident groups such as Han, Yi, Lisu, and Miao, it has poor economic performance but rich indigenous cultural wellness knowledge and unique wellness attributes. Panzhihua city is now attracting an increasing number of seasonal wellness migrants from different provinces of China. According to the records of the local county tourism bureau, nearly 30,148,100 visitors came for wellness in 2019, many of whom are elderly people (Panzhihua Tourism Bureau, 2020). Meanwhile, residents have already taken part in the Kangyang tourism industry for those seasonal wellness stayers through accommodation and transportation. The case study was adopted, an empirical inquiry approach appropriate to study research problems in an explanatory way [67].

Five target areas of MKT destinations are selected from Panzhihua City for research, Puda, Hemenkou, Wuben, Zhuanxu and Hongge, the popular Kangyang tourism destinations at East District, West District, Renhe District, Miyi County, and Yanbian County. The five destinations are formed relying on the characteristic resource environment of Panzhihua. Its diverse and rich natural resources can help to preserve and improve the health of people and extend their life expectancy: a favorable climate and range of ecological zones, forest, forest-steppe and steppe and mountainous areas, a unique microclimate of caves, a wide range of natural rivers, therapeutic mud and so on. Due to its advantageous location, around $1200 \mathrm{~m}$ latitude in mountain-based areas, ample natural resources and facilities, people living in urban areas with strong interests in health and wellness represent increasing demand for traveling for weekend leisure destinations.

\subsection{Research Method}

Some scholars used SEM to analyze satisfaction from the perspective of tourists. Catarina, Rui and Stanislava (2021) used SEM to analyze the relationship between image, satisfaction, destination and product post-visit behaviors. Lee et al. (2021) examined tourists' experiences are associated with a Value-Attitude-Behavior (VAB) model using SEM analysis [46]. Li, Fang and Soutar (2021) used the SEM technique to analyze tourists' experiences, post-trip destination image, satisfaction and loyalty in an ecotourism context [38]. The study used SEM to analyze the relationship among experiential value, satisfaction and behavior intentions. Many factors affect the likelihood of tourist participation in MKT, and many data cover a wide range.

\section{Data Collection and Analysis}

\subsection{Data Collection}

The study focuses on tourists traveling from MKT destination in Panzhihua City. Two reasons explain the focus on these tourists. First, many people want to experience MKT, who are the priority targets for many MKT planners. Second, although current studies have investigated tourists doing wellness tourism in China, few focus on this market segment. It is necessary to study MKT tourists because of their different behaviors during traveling.

First, a pilot test was conducted on Miyi and Yanbian counties of Panzhihua and 85 questionnaires were distributed, with their content adjusted after reliability and validity analysis and expert consultation. In the formal investigation, questionnaires were issued to tourists in the MKT areas of five destinations in Panzhihua City (East District, West District, Renhe District, Miyi County, and Yanbian County). Self-filled and interviewed structured questionnaires were used to obtain data, the latter especially for elderly tourists with poor eyesight or lacking writing ability. Ten researchers collected these data from the middle of 2020 to the beginning of 2021 about the above five MKT destinations in Panzhihua from 
the selection criteria who are adults over 18 years old. A Mandarin-speaking researcher accompanied all visits to ensure the quality of data collection. Before leaving the Kangyang tourism destination, each tourist was approached and asked for their consent to complete a questionnaire. Researchers could answer any questions. A total of 550 questionnaires were distributed, with 510 recovered and 500 valid counterparts obtained after preliminary verification. SPSS 26.0 and AMOS 23.0 were used to process data and simplify the impact factors, respectively.

\subsection{Questionnaire Design}

Among all 38 questions, 30 used the Likert five-level scale. Tourists are scored from 1 to 5 points corresponding to very unimportant-very important items, as shown in Table 1. For example, question 1 asked about unobstructed traffic accessibility; individuals opt for 1 when they consider that it is a very unimportant factor that affects their likelihood to go for MKT again or recommend MKT to other persons.

Table 1. Monetization form of scale items.

\begin{tabular}{ccccc}
\hline Very Important & Important & General & Not Important & Very Unimportant \\
\hline 5 & 4 & 3 & 2 & 1 \\
\hline
\end{tabular}

According to research needs, the questionnaire is designed with two parts. The first part covers demographic information, including gender, age, education level, travel experience, etc. The second part summarizes important factors based on in-depth interviews with practitioners and literature reviews and verifies the real needs of tourists for Kangyang tourism in mountain areas. (Table 2)

Table 2. Questionnaire design.

\begin{tabular}{|c|c|c|c|c|}
\hline & $\begin{array}{l}\text { Question } \\
\text { Number }\end{array}$ & Item & Action Item & Source \\
\hline \multirow{7}{*}{ Functional value (F1) } & Q1 & Traffic & \multirow{7}{*}{$\begin{array}{c}\text { Unobstructed traffic accessibility } \\
\text { Reasonable planning and design of } \\
\text { MKT destinations } \\
\text { The service to be efficient } \\
\text { Supporting facilities such as catering, shopping, } \\
\text { communication, parking facilities, public } \\
\text { restrooms, and identification systems in the } \\
\text { MKT areas are complete } \\
\text { The public security situation and activity } \\
\text { facilities in the MKT are very safe } \\
\text { Accompanying medical staff } \\
\text { The government monitors the environmental } \\
\text { impact of MKT }\end{array}$} & [11] \\
\hline & Q2 & Planning and design rationality & & {$[13,14]$} \\
\hline & Q3 & Service efficiency & & {$[46,53,85,86]$} \\
\hline & Q4 & Supporting facilities & & {$[11,16,17,70]$} \\
\hline & Q5 & Public security and activity safety & & {$[17,54]$} \\
\hline & Q6 & medical personnel & & {$[11,55]$} \\
\hline & Q7 & Environmental protection & & {$[3,56]$} \\
\hline \multirow{6}{*}{ Contextual value (F2) } & Q8 & Personality signs & \multirow{6}{*}{$\begin{array}{c}\text { The popularity of MKT destinations } \\
\text { Beautiful and pleasant landscape environment } \\
\text { in the mountains } \\
\text { Mountain vegetation coverage } \\
\text { Characteristic architectural design, celebrity } \\
\text { homes or heritage sites } \\
\text { The service staff is patient, warm and friendly } \\
\text { Suitable mountain climate conditions }\end{array}$} & {$[1,59,60]$} \\
\hline & Q9 & Landscape environment & & [14] \\
\hline & Q10 & Vegetation coverage & & {$[12,15,26]$} \\
\hline & Q11 & Iconic buildings & & \\
\hline & Q12 & Service attitude & & [61] \\
\hline & Q13 & Climatic conditions & & [26] \\
\hline \multirow{6}{*}{ Emotional value (F3) } & Q14 & Relaxation and excitement & $\begin{array}{l}\text { MKT festival activities make tourists feel rich } \\
\text { and diverse (such as flower viewing, rock } \\
\text { climbing, rafting, hot springs, etc.) }\end{array}$ & {$[11,65,70,87]$} \\
\hline & Q15 & Travel freshness & $\begin{array}{c}\text { MKT experience activities make tourists feel } \\
\text { very fresh }\end{array}$ & {$[11]$} \\
\hline & Q16 & Comfort & $\begin{array}{c}\text { Feeling very relaxed, leisure and comfortable } \\
\text { during the MKT }\end{array}$ & {$[3,54,55,66]$} \\
\hline & Q17 & Fun of knowledge and stories & $\begin{array}{c}\text { The tour guide can explain different knowledge } \\
\text { and funny stories to let tourists forget the daily } \\
\text { trivia and troubles }\end{array}$ & {$[67]$} \\
\hline & Q18 & Leisure and fitness of group activities & $\begin{array}{l}\text { Hold more outdoor leisure and fitness group } \\
\text { activities such as Tai Chi, yoga, hiking, etc. to } \\
\text { harmonize with the emotions of peers }\end{array}$ & [22] \\
\hline & Q19 & Happiness of communication & $\begin{array}{c}\text { Share of what tourists have seen interestedly } \\
\text { and heard with peers }\end{array}$ & [26] \\
\hline
\end{tabular}


Table 2. Cont.

\begin{tabular}{|c|c|c|c|c|}
\hline & $\begin{array}{l}\text { Question } \\
\text { Number }\end{array}$ & Item & Action Item & Source \\
\hline \multirow{4}{*}{ Cognitive value (F4) } & Q20 & Knowledge acquisition & $\begin{array}{c}\text { Gained new knowledge during the experience of } \\
\text { participation in MKT activities }\end{array}$ & {$[17]$} \\
\hline & Q21 & Experience of the local culture & $\begin{array}{l}\text { Interactive experience with locals let tourists } \\
\text { understand the characteristic culture }\end{array}$ & {$[3,26]$} \\
\hline & Q22 & Experiential exchange & $\begin{array}{l}\text { Experience and exchange during the mountain } \\
\text { wellness journey benefit tourists }\end{array}$ & \\
\hline & Q23 & Participation of competition item & $\begin{array}{l}\text { Participate in some competitions during the } \\
\text { mountain rehabilitation journey to broaden } \\
\text { tourists' horizons }\end{array}$ & [17] \\
\hline \multirow{3}{*}{ Economic value (F5) } & Q24 & Reasonable price & \multirow{3}{*}{$\begin{array}{l}\text { Reasonable consumption level during MKT } \\
\text { Good value for this trip } \\
\text { Convenient internal transportation (low cost of } \\
\text { travel time, transportation, energy, etc.) }\end{array}$} & [43] \\
\hline & Q25 & Value for money & & {$[46,56,70,71]$} \\
\hline & Q26 & time-saving and labor-saving & & {$[11]$} \\
\hline \multirow[b]{2}{*}{ Satisfaction (F6) } & Q27 & Travel expectations & \multirow{2}{*}{$\begin{array}{c}\text { The MKT project meets tourists' expectations. } \\
\text { Compared with other health tourism, the } \\
\text { recognition of mountain Kangyang } \\
\text { tourism destinations }\end{array}$} & {$[78,88]$} \\
\hline & Q28 & Travel recognition & & [78] \\
\hline \multirow{2}{*}{$\begin{array}{l}\text { Post-trip behavior } \\
\text { intention (F7) }\end{array}$} & Q29 & Willingness to revisit & \multirow{2}{*}{$\begin{array}{l}\text { Willing to go to this mountain health } \\
\text { tourism again } \\
\text { Willing to recommend a mountain recreation } \\
\text { tour to friends and relatives }\end{array}$} & [76] \\
\hline & Q30 & Willingness to recommend & & {$[75]$} \\
\hline
\end{tabular}

\subsection{Data Analysis}

Table 3 reveals that there are slightly more women than men, and the major population is $21-40$ years old $(22.4 \%)$ and $51-60$ years old $(23.4 \%)$. Tourists of MKT are mostly from enterprises and institutions, and undergraduates dominate in terms of education. Lowand middle-income groups make up the majority. Most of them have good health, and many have 2-5 times of MKT. Tourists are willing to spend less than 7 days on Kangyang tourism in mountain areas.

Table 3. Data analysis of Panzhihua Tourist Samples.

\begin{tabular}{|c|c|c|c|c|c|c|c|}
\hline Item & Classification & $\begin{array}{c}\text { Number of } \\
\text { People }\end{array}$ & Percentage & Item & Classification & $\begin{array}{c}\text { Number of } \\
\text { People }\end{array}$ & Percentage \\
\hline \multirow{2}{*}{ gender } & male & 214 & 42.8 & \multirow{25}{*}{ Job background } & $\begin{array}{l}\text { Enterprise/company middle } \\
\text { and senior management }\end{array}$ & 30 & 6 \\
\hline & Female & 286 & 57.2 & & $\begin{array}{l}\text { Enterprise/company } \\
\text { grassroots management }\end{array}$ & 60 & 12 \\
\hline \multirow{6}{*}{ age } & Under 20 & 39 & 7.8 & & Private owners & 29 & 5.8 \\
\hline & $21-30$ & 112 & 22.4 & & Civil servant & 30 & 6 \\
\hline & $31-40$ & 117 & 23.4 & & Medical staff & 20 & 4 \\
\hline & $41-50$ & 98 & 19.6 & & Soldier & 2 & 0.4 \\
\hline & $51-60$ & 105 & 21 & & Lawyer & 5 & 1 \\
\hline & Over 60 & 29 & 5.8 & & Teacher & 49 & 9.8 \\
\hline \multirow{5}{*}{ Education } & $\begin{array}{l}\text { Below junior } \\
\text { high school }\end{array}$ & 79 & 15.8 & & Administrative & 2 & 0.4 \\
\hline & High school & 88 & 17.6 & & Finance & 8 & 1.6 \\
\hline & Junior college & 124 & 24.8 & & Personnel & 4 & 0.8 \\
\hline & Undergraduate & 202 & 40.4 & & Technology & 15 & 3 \\
\hline & $\begin{array}{l}\text { Master degree } \\
\text { and above }\end{array}$ & 7 & 1.4 & & Market sales & 9 & 1.8 \\
\hline \multirow{5}{*}{ income } & Below 2000 & 116 & 23.2 & & Style & 3 & 0.6 \\
\hline & 2000-3999 & 143 & 28.6 & & Worker & 15 & 3 \\
\hline & $4000-5999$ & 134 & 26.8 & & Driver & 4 & 0.8 \\
\hline & 6000-7999 & 65 & 13 & & Farmer & 7 & 1.4 \\
\hline & 8000 and above & 42 & 8.4 & & Temporary Worker & 3 & 0.6 \\
\hline \multirow{3}{*}{ State of health } & excellent & 324 & 64.8 & & \multirow{3}{*}{$\begin{array}{c}\text { School student } \\
\text { Babysitter } \\
\text { /Housekeeping Service Staff } \\
\text { Retirement }\end{array}$} & 71 & 14.2 \\
\hline & Sub-health & 173 & 34.6 & & & 2 & 0.4 \\
\hline & Very bad & 2 & 0.4 & & & 48 & 9.6 \\
\hline \multirow{4}{*}{$\begin{array}{l}\text { Number of participating } \\
\text { health tours }\end{array}$} & \multirow{4}{*}{$\begin{array}{l}1 \text { time } \\
2-5 \text { times } \\
\text { More than } 5 \\
\text { times } \\
\text { Never } \\
\text { participated }\end{array}$} & 72 & 14.4 & & $\begin{array}{l}\text { Housewife } \\
\text { /homeowner }\end{array}$ & 3 & 0.6 \\
\hline & & 165 & 33 & & part time worker & 6 & 1.2 \\
\hline & & 153 & 30.6 & & Freelancer & 56 & 11.2 \\
\hline & & 110 & 22 & & No job & 19 & 3.8 \\
\hline \multirow{6}{*}{ Willing travel time } & 1 day & 103 & 20.6 & & \multirow{6}{*}{ Total } & \multirow{6}{*}{500} & \multirow{6}{*}{100} \\
\hline & $1-3$ days & 192 & 38.4 & & & & \\
\hline & 5-7 days & 146 & 29.2 & & & & \\
\hline & \multirow{2}{*}{$\begin{array}{l}\text { Half a month } \\
\text { More than one } \\
\text { month }\end{array}$} & 38 & 7.6 & & & & \\
\hline & & 21 & 4.2 & & & & \\
\hline & Total & 500 & 100 & & & & \\
\hline
\end{tabular}




\subsection{Reliability and Validity}

SPSS 26.0 software was used to perform KMO and Bartlett sphericity test on the data, specific results shown in Table 4. KMO sampling appropriateness of factors F1-F8 is $0.5-0.729$, and comprehensive validity is 0.834 and above. Bartlett's sphericity test $p=0000$; therefore, all factors are significant. The validity between factors is fair so that data can be analyzed using the factor method.

Table 4. Validity test.

\begin{tabular}{ccc}
\hline Factor & $\begin{array}{c}\text { KMO Sampling } \\
\text { Appropriateness Quantity }\end{array}$ & Significance \\
\hline F1 & 0.729 & \\
F2 & 0.669 & \\
F3 & 0.761 & \\
F4 & 0.648 & \\
F5 & 0.563 & \\
F6 & 0.574 & \\
F7 & 0.5 & \\
Comprehensive validity & 0.834 & \\
\hline
\end{tabular}

According to the literature review, many factors affect tourists' MKT activities. A total of 7 latent variables and 30 observation variables were included. The reliability test was analyzed using SPSS 26.0. The reliability $\alpha$ range of F1-F8 is between $0.50-0.833$, and the comprehensive reliability $\alpha$ value is 0.876 . Therefore, the reliability is better, as shown in Table 5.

Table 5. Descriptive statistics and reliability of the scale.

\begin{tabular}{|c|c|c|c|c|c|c|c|}
\hline Latent Variable & & Observed Variable & Mean & $\begin{array}{c}\text { Standard } \\
\text { Deviation }\end{array}$ & Variance & $\alpha$ & $\begin{array}{c}\text { Comprehensive } \\
\alpha\end{array}$ \\
\hline \multirow{8}{*}{$\begin{array}{l}\text { Functional value } \\
\qquad(\mathrm{F} 1)\end{array}$} & FV1 & Traffic & 4.05 & 0.91 & 0.829 & \multirow{7}{*}{0.593} & \multirow{30}{*}{0.876} \\
\hline & FV2 & Planning and design rationality & 4.03 & 0.805 & 0.649 & & \\
\hline & FV3 & Service efficiency & 4.2 & 0.738 & 0.545 & & \\
\hline & FV4 & Supporting facilities & 4.16 & 0.762 & 0.581 & & \\
\hline & FV5 & Public security and activity safety & 3.59 & 0.903 & 0.815 & & \\
\hline & FV6 & Medical personnel & 3.99 & 0.741 & 0.549 & & \\
\hline & FV7 & Conservation of ecosystem & 3.97 & 0.831 & 0.691 & & \\
\hline & SV1 & Reputation & 3.54 & 0.948 & 0.898 & \multirow{5}{*}{0.626} & \\
\hline \multirow{4}{*}{$\begin{array}{l}\text { Contextual value } \\
\text { (F2) }\end{array}$} & SV2 & Landscape environment & 4.09 & 0.737 & 0.543 & & \\
\hline & SV3 & Vegetation coverage & 4.13 & 0.71 & 0.505 & & \\
\hline & SV4 & Iconic building & 3.69 & 0.836 & 0.699 & & \\
\hline & SV5 & Service attitude & 4.07 & 0.784 & 0.615 & & \\
\hline \multirow{6}{*}{$\begin{array}{l}\text { Emotional value } \\
\text { (F3) }\end{array}$} & SV6 & Climatic conditions & 4.12 & 0.759 & 0.576 & \multirow{6}{*}{0.673} & \\
\hline & EV1 & Relaxation and excitement in MKT & 3.65 & 0.897 & 0.805 & & \\
\hline & EV2 & Freshness of MKT & 3.8 & 0.793 & 0.629 & & \\
\hline & EV3 & Comfortableness of MKT & 3.49 & 0.887 & 0.787 & & \\
\hline & EV4 & $\begin{array}{c}\text { Funny knowledge and culture in } \\
\text { MKT }\end{array}$ & 3.76 & 0.893 & 0.798 & & \\
\hline & EV5 & $\begin{array}{l}\text { Leisure and fitness of group } \\
\text { activities in MKT }\end{array}$ & 3.79 & 0.813 & 0.66 & & \\
\hline \multirow{5}{*}{ Cognitive Value (F4) } & EV6 & Happiness of communication & 3.83 & 0.794 & 0.63 & \multirow{5}{*}{0.652} & \\
\hline & CV1 & Knowledge acquisition & 3.82 & 0.86 & 0.74 & & \\
\hline & $\mathrm{CV} 2$ & Experience of the local culture & 3.25 & 1.032 & 1.066 & & \\
\hline & CV3 & Experiential exchange & 3.41 & 0.975 & 0.951 & & \\
\hline & $\mathrm{CV} 4$ & $\begin{array}{l}\text { Participation in mountain } \\
\text { competition }\end{array}$ & 3.77 & 0.903 & 0.816 & & \\
\hline \multirow{3}{*}{ Economic value (F5) } & EVT1 & Reasonable price & 4.04 & 0.855 & 0.732 & \multirow{3}{*}{0.50} & \\
\hline & EVT2 & Value for money & 4.16 & 0.789 & 0.622 & & \\
\hline & EVT3 & Time-saving and labor-saving & 3.99 & 0.843 & 0.711 & & \\
\hline \multirow{2}{*}{ Satisfaction (F6) } & TS1 & Travel expectations & 3.84 & 0.781 & 0.61 & \multirow{2}{*}{0.642} & \\
\hline & TS2 & Travel recognition & 3.8 & 0.789 & 0.622 & & \\
\hline \multirow{2}{*}{$\begin{array}{l}\text { post-trip behavior } \\
\text { intention (F7) }\end{array}$} & RI1 & Willingness to revisit & 3.7 & 0.841 & 0.707 & \multirow{2}{*}{0.738} & \\
\hline & $\mathrm{RI} 2$ & Willingness to recommend & 3.83 & 0.797 & 0.636 & & \\
\hline
\end{tabular}




\subsection{Theoretical Model Construction}

According to the SEM, a hypothetical analysis among various factors was carried out. The hypothetical model "experiential value-satisfaction-post-trip behavior intention" was constructed in the MKT context.

According to the literature review, there are seven dimensions: functional value (F1), contextual value (F2), emotional value (F3), cognitive Value (F4), economic value (F5), satisfaction (F6) and post-trip behavior intention (F7); as many as 30 observed variables of MKT existed, and the relationship between the variables was complicated. In SEM, the AMOS23.0 software was used to conduct the theoretical test to study the correlation between experiential value, satisfaction and intentions. Figure 1 shows the revised standard model. The relationship between factors of the model is significant, as shown in Table 6 . $p<0.001$, that is $p={ }^{* * *}$, indicates that the relationship between factors is significant, and the hypothesis is true; If $p>\alpha(\alpha=0.1,0.05,0.01)$, the hypothesis is not true.

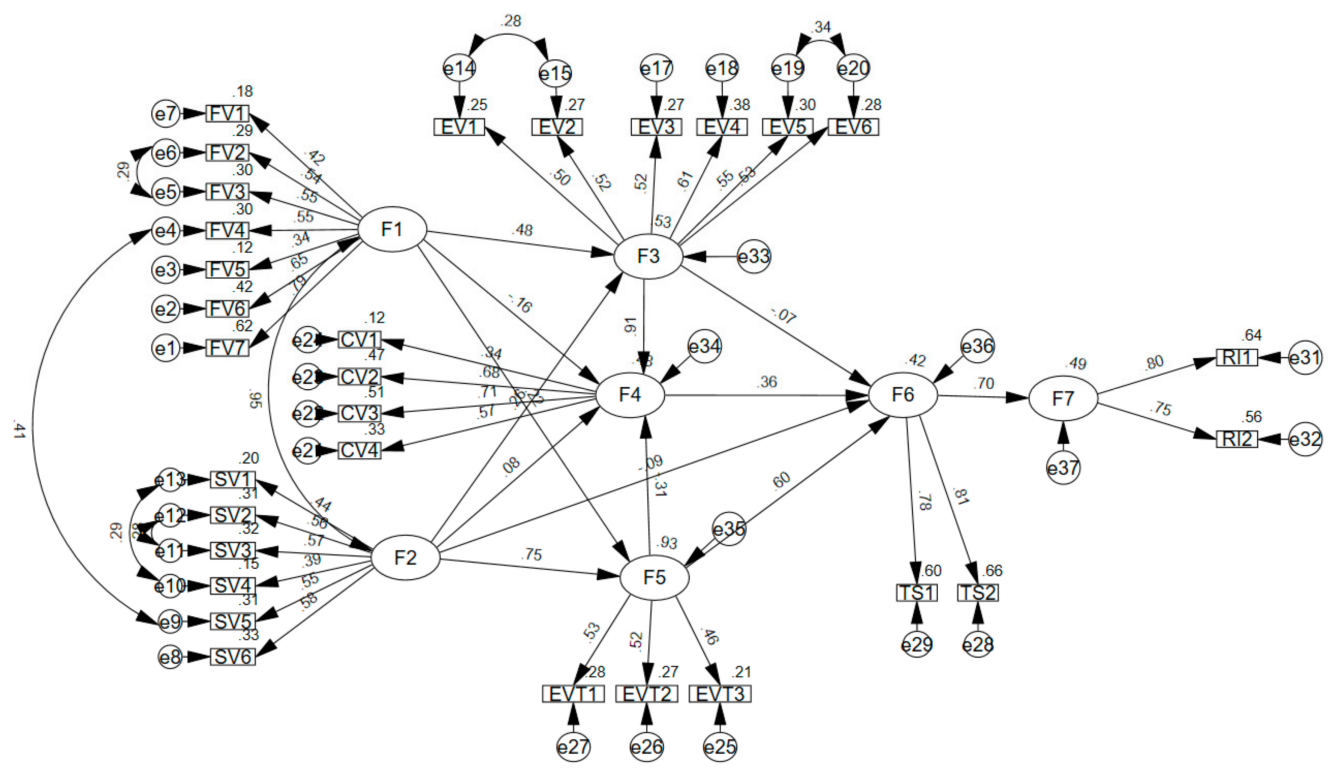

Figure 1. Standardization coefficient of structural equation path. Note: F1—functional value, F2-contextual value, F3-emotional value, F4 - cognitive value, F5—economic value, F6—satisfaction, F7—behavior willingness.

Table 6. Model measurement results.

\begin{tabular}{|c|c|c|c|c|c|c|c|c|}
\hline Hypothesis & & & & Estimate & S.E. & C.R. & $p$ & Test Result \\
\hline H1a & F3 (emotional value) & $<-$ & F1 (Functional Value) & 0.269 & 0.148 & 1.816 & 0.069 & not support \\
\hline $\mathrm{H} 2 \mathrm{a}$ & F3 (emotional value) & $<-$ & F2 (Contextual Value) & 0.140 & 0.313 & 0.446 & 0.655 & not support \\
\hline $\mathrm{H} 1 \mathrm{c}$ & F4 (Cognitive value) & $<-$ & F1 (Functional Value) & -0.292 & 0.222 & -1.312 & 0.190 & not support \\
\hline $\mathrm{H} 2 \mathrm{c}$ & F4 (Cognitive value) & $<-$ & F2 (Contextual Value) & 0.111 & 0.438 & 0.254 & 0.799 & not support \\
\hline $\mathrm{H} 1 \mathrm{~b}$ & F5 (economic value) & $<-$ & F1 (Functional Value) & 0.360 & 0.171 & 2.102 & $* * *$ & support \\
\hline $\mathrm{H} 3 \mathrm{c}$ & F6 (satisfaction) & $<-$ & F4 (Cognitive Value) & 0.449 & 0.142 & 3.168 & $* * *$ & support \\
\hline $\mathrm{H} 3 \mathrm{~b}$ & F6 (satisfaction) & $<-$ & F3 (Emotional Value) & -0.143 & 0.262 & -0.545 & 0.586 & not support \\
\hline $\mathrm{H} 2 \mathrm{~b}$ & F5 (economic value) & $<-$ & F2 (Contextual Value) & 0.124 & 0.346 & 0.359 & 0.719 & not support \\
\hline $\mathrm{H} 3 \mathrm{a}$ & F6 (satisfaction) & $<-$ & F2 (Contextual Value) & 0.743 & 0.194 & 3.829 & $* * *$ & support \\
\hline $\mathrm{H} 3 \mathrm{~d}$ & F6 (satisfaction) & $<-$ & F5 (Economic Value) & 0.523 & 0.292 & 6.128 & $* * *$ & support \\
\hline \multirow[t]{15}{*}{$\mathrm{H} 4$} & F7 (behavior intention) & $<-$ & F6 (Satisfaction) & 0.655 & 0.076 & 8.655 & $* * *$ & Support \\
\hline & FV7 & $<-$ & F1 (Functional Value) & 0.335 & 0.325 & 4.322 & $* * *$ & support \\
\hline & FV6 & $<-$ & F1 (Functional Value) & 0.531 & 0.046 & 11.568 & $* * *$ & support \\
\hline & FV5 & $<-$ & F1 (Functional Value) & 0.312 & 0.060 & 5.210 & $* * *$ & support \\
\hline & FV4 & $<-$ & F1 (Functional Value) & 0.446 & 0.048 & 9.213 & $* * *$ & support \\
\hline & FV3 & $<-$ & F1 (Functional Value) & 0.429 & 0.047 & 9.042 & $* * *$ & support \\
\hline & FV2 & $<-$ & F1 (Functional Value) & 0.458 & 0.052 & 8.866 & $* * *$ & support \\
\hline & FV1 & $<-$ & F1 (Functional Value) & 0.399 & 0.062 & 6.460 & $* * *$ & support \\
\hline & SV6 & $<-$ & F2 (Contextual Value) & 0.446 & 0.363 & 5.032 & $* * *$ & support \\
\hline & SV5 & $<-$ & F2 (Contextual Value) & 0.992 & 0.137 & 7.228 & $* * *$ & support \\
\hline & SV4 & $<-$ & F2 (Contextual Value) & 0.720 & 0.140 & 5.152 & $* * *$ & support \\
\hline & SV3 & $<-$ & F2 (Contextual Value) & 0.911 & 0.128 & 7.120 & $* * *$ & support \\
\hline & SV2 & $<-$ & F2 (Contextual Value) & 0.944 & 0.134 & 7.039 & $* * *$ & support \\
\hline & SV1 & $<-$ & F2 (Contextual Value) & 0.980 & 0.164 & 5.980 & $* * *$ & support \\
\hline & EV1 & $<-$ & F3 (Emotional Value) & 0.465 & 0.237 & 6.320 & $* * *$ & support \\
\hline
\end{tabular}


Table 6. Cont.

\begin{tabular}{|c|c|c|c|c|c|c|c|}
\hline Hypothesis & & & Estimate & S.E. & C.R. & $p$ & Test Result \\
\hline EV2 & $<-$ & F3 (Emotional Value) & 0.948 & 0.121 & 7.828 & $* * *$ & support \\
\hline EV3 & $<-$ & F3 (Emotional Value) & 1.068 & 0.158 & 6.777 & $* * *$ & support \\
\hline $\mathrm{E} 4$ & $<-$ & F3 (Emotional Value) & 1.288 & 0.186 & 6.912 & $* * *$ & support \\
\hline EV5 & $<-$ & F3 (Emotional Value) & 1.031 & 0.160 & 6.447 & $* * *$ & support \\
\hline EV6 & $<-$ & F3 (Emotional Value) & 0.974 & 0.151 & 6.454 & $* * *$ & support \\
\hline CV4 & $<-$ & F4 (Cognitive Value) & 1.230 & 0.532 & 6.323 & $* * *$ & support \\
\hline CV3 & $<-$ & F4 (Cognitive Value) & 1.307 & 0.136 & 9.625 & $* * *$ & support \\
\hline CV2 & $<-$ & F4 (Cognitive Value) & 1.324 & 0.146 & 9.047 & $* * *$ & support \\
\hline CV1 & $<-$ & F4 (Cognitive Value) & 0.558 & 0.094 & 5.973 & $* * *$ & support \\
\hline EVT3 & $<-$ & F5 (Economic Value) & 0.836 & 0.132 & 5.367 & $* * *$ & support \\
\hline EVT2 & $<-$ & F5 (Economic Value) & 1.020 & 0.149 & 6.865 & $* * *$ & support \\
\hline EVT1 & $<-$ & F5 (Economic Value) & 1.022 & 0.185 & 5.536 & $* * *$ & support \\
\hline TS2 & $<-$ & F6 (Satisfaction) & 1.032 & 0.187 & 5.832 & $* * *$ & support \\
\hline TS1 & $<-$ & F6 (Satisfaction) & 0.939 & 0.070 & 13.406 & $* * *$ & support \\
\hline RI1 & $<-$ & F7 (Behavior Intention) & 1.021 & 0.082 & 12.030 & $* * *$ & support \\
\hline RI2 & $<-$ & F7 (Behavior Intention) & 0.883 & 0.079 & 11.234 & $* * *$ & support \\
\hline
\end{tabular}

\subsection{Hypothesis Verification}

As shown in Table 6, in addition to the hypothesis between some latent variables did not reach a significant relationship. From Table 6, $p$ value $>\alpha$, thus H1a, H2a, H1c, H2c, H3b and $\mathrm{H} 2 \mathrm{~b}$ are not supported. That is, the results showed that the following hypotheses were not supported: "Functional value (F1) and contextual value (F2) directly influence the emotional value (F3) in MKT" (H1a, H2a); "Functional value (F1) directly influences cognitive value (F4) in $\mathrm{MKT}^{\prime}$ (H1c); "Contextual value (F2) directly influence cognitive value (F4) in MKT" (H2c); "Emotional value (F3) directly influence tourist satisfaction (F6) in MKT" (H3b); "Contextual value (F2) directly influence economic value (F5) in MKT" (H2b).

Meanwhile, all remaining variables meet the requirement of significance. $\mathrm{H} 1 \mathrm{~b}, \mathrm{H} 3 \mathrm{c}$, $\mathrm{H} 3 \mathrm{a}, \mathrm{H} 3 \mathrm{~d}$ and $\mathrm{H} 4$ are supported because the $p={ }^{* * *}$. Hence, the results showed that the following hypotheses were supported: "Functional value (F1) directly influences economic value (F5) in MKT" (H1b); "Cognitive value (F4) directly influences tourist satisfaction (F6) in $\mathrm{MKT}^{\prime \prime}$ (H3c); "Contextual value (F2) directly influences tourist satisfaction (F6) in MKT" (H3a); "Economic value (F5) directly influences tourist satisfaction (F6) in MKT" (H3d); "visitor satisfaction (F6) directly influences behavior intention (F7) in MKT" (H4).

\subsection{Goodness of Fit Statistics}

Details results of the revised SEM are shown in Table 7. The absolute fit index and the simple fit index of the SEM of "experiential value-satisfaction-post-trip behavior intention" of MKT are both in an ideal state. The value of the value-added fitting degree fails to reach the ideal state value of the index value and can only achieve general results in the fitting situation.

Table 7. Goodness of fit statistics.

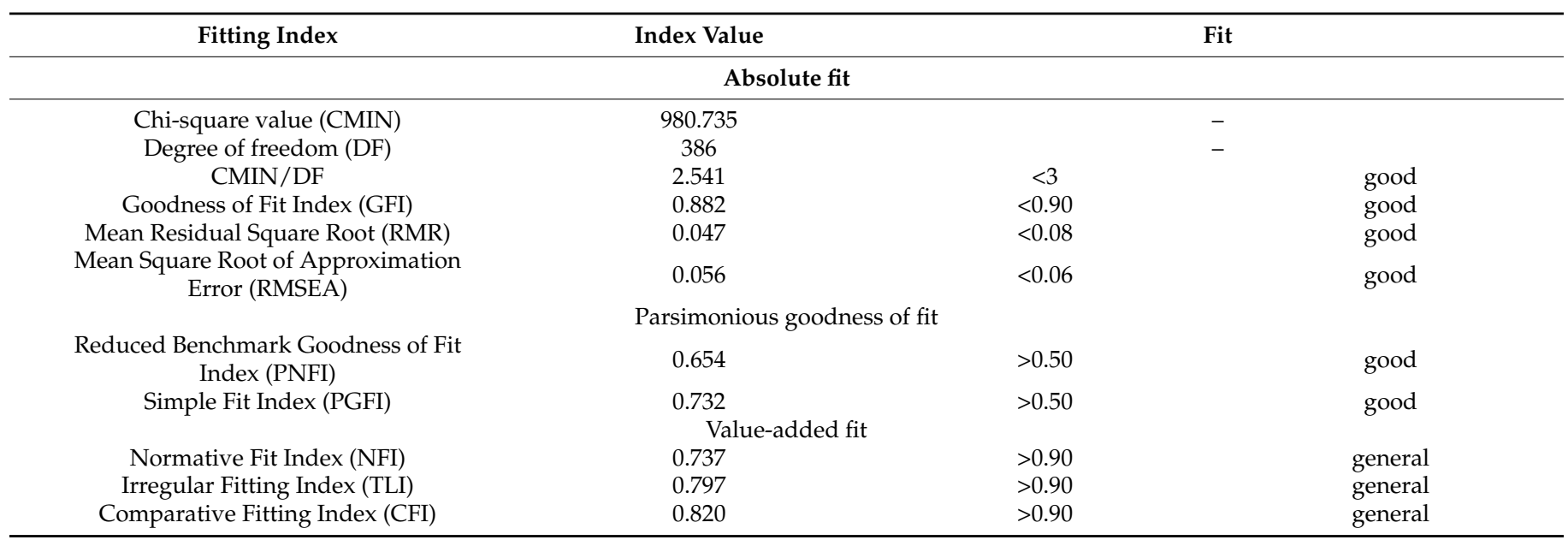


Generally speaking, with a sample size of 500, all indicators are acceptable, and the model goodness-of-fit is relatively good. In model index results, the chi-square degree of freedom CMIN/DF value is 2.541, less than the upper limit requirement of index 3 . The value of the fit index GFI is 0.882 , failing to reach above but close to 0.9 . Therefore, it is not in the acceptable range; the average residual square root RMR value is 0.047 , less than the upper limit of the index value requirement of 0.08 ; the average approximate square root error RMSEA value is 0.056 , less than the index upper reference limit of 0.06; the parsimonious benchmark goodness of fit index PNF value is 0.654 , and the value of the simplified fitting index PGFI is 0.732 , both greater than 0.5 (the lower limit index reference value); the value of the standard fitting index NFI is 0.737 , less than the ideal value index of 0.9 or more but greater than 0.7 and close to 0.8 , in an acceptable range; the irregular fitting index TLI value of 0.797 fails to reach the ideal value of 0.9 but close to 0.8 in the acceptable range; the comparative fitting index CFI value of 0.820 fails to reach the ideal standard of 0.9 but greater than 0.8 in the acceptable range.

\section{Results}

The factors identified in Section 2 of this research covering various aspects of tourists' experiential value have a complex relationship. Therefore, AOMS23.0 was used to construct an SEM of "experiential value-satisfaction-post-trip behavior intentions" in MKT, as shown in Figure 1. Under the hypothesis verification of ensuring the influences between various potential variables, the specific influencing factors of the MKT by each observation variable need to be judged according to the specific path value of each observation variable. In order to enhance the likelihood to re-visit and recommend MKT after site visit, destinations managers should know how to optimize the allocation of resources under the construction of MKT and invest resources in the specific construction and development projects of the health tourism industry.

\subsection{Functional Value}

As shown in Figure 1, for the MKT functional value, the standardized path coefficients of the observed variables, including traffic (FV1), planning and design rationality (FV2), service efficiency (FV3), supporting facilities (FV4), public security and activity safety (FV5), medical service (FV6), and ecological environment protection (FV7) are $0.42,0.54,0.55$, $0.55,0.34,0.65,0.79$. The path value of ecological environment protection $(F V 7,0.79)$ is the highest, the medical service (FV6, 0.65) is the second-highest. Therefore, MKT managers need to allocate more construction resources to ecological and environmental protection and medical service to leave a good impression on tourists. The path value of service efficiency (FV3, 0.55), supporting facilities (FV4, 0.55), and planning and design rationality (FV2, 0.54), and the path value of the planning and design rationality (FV2, 0.54) is only a little smaller than 0.55 , suggesting that it has a significant impact on functional value. Thus, improvement in supporting facilities and the improvement in service efficiency and planning and design is important in MKT destination sustainability. In contrast, the impacts of traffic (FV1, 0.42), public security and activity safety (FV5, 0.34) on the functional value are relatively small but are still great, indicating that traffic, public security and activity safety cannot be ignored.

\subsection{Contextual Value}

The path values of observed variables including reputation (SV1), landscape environment (SV2), vegetation coverage (SV3), iconic buildings (SV4), service attitude (SV5), and climate conditions (SV6) are $0.44,0.56,0.57,0.39,0.55,0.58$, respectively. The path value of climate conditions $(\mathrm{SV} 6,0.58)$ is the largest, suggesting that this factor plays a key role in the construction of contextual value. The landscape environment $(\mathrm{SV} 2,0.56)$, vegetation coverage (SV3, 0.57) and service attitude (SV5, 0.55) are close to climate conditions (SV6, 0.58), indicating landscape environment, vegetation coverage, service attitude also play pivotal roles. Therefore, the resources invested in these four aspects should be reasonably allocated 
according to their contributions. The reputation (SV1, 0.44) and iconic buildings (SV4, 0.39) are relatively small compared to the values of other variables. Although the contributions of the reputation and iconic buildings are small, they are still significant.

\subsection{Emotional Value}

The path values of observed variables of the emotional value, including relaxation and excitement in MKT (EV1), tourism freshness of MKT (EV2), comfortableness in MKT (EV3), funny knowledge and culture (EV4), leisure and fitness of group activities (EV5) and happiness of communication (EV6) are $0.50,0.52,0.52,0.61,0.55,0.53$, respectively. The path value of funny knowledge and culture (EV4, 0.61) is the largest, indicating the fun of tourism knowledge culture of MKT plays a key role in the construction of emotional value. The relaxation and excitement (EV1, 0.50), tourism freshness (EV2, 0.52), tourism comfortableness $(\mathrm{EV} 3,0.52)$, leisure and fitness of group activities $(\mathrm{EV} 5,0.55)$ and sharing willingness (EV6, 0.53) are all between $0.50-0.55$, indicating tourism relaxation and excitement, tourism freshness, tourism comfort, fun of group activities, and happy communications have significant impacts on emotional value. The quality of the construction in these aspects plays an important role in the sentimental value judgment of tourists.

\subsection{Cognitive Value}

The path values of observed variables of cognitive value, including the knowledge acquisition (CV1), the experience of the local culture (CV2), experience exchange of MKT (CV3), and participation of mountain competition projects (CV4) are $0.34,0.68,0.71$, and 0.57 , respectively. In terms of the cognitive value of tourists, the experience exchange of MKT (CV3, 0.71$)$ plays the most key role, and the local culture (CV2, 0.68) and participation in mountain competition projects $(\mathrm{CV} 4,0.57)$ are also important. Although knowledge acquisition (CV1, 0.34) is important, it has a smaller contribution value compared with the other three factors. Therefore, the providers of MKT should pay attention to invest more resources in the local culture development, and provide opportunities for tourists experiences sharing with other people. By the way, various competition activities and knowledge acquisition can not be ignored.

\subsection{Economic Value}

The path values of the observed variables of economic value, including reasonable price (EVT1), value for money (EVT2), and time-saving and labor-saving (EVT3) are 0.53, 0.52 , and 0.46 , respectively. The reasonable price (EVT1, 0.53) is the largest, followed by value for money (EVT2, 0.52), and the smallest is the time-saving and labor-saving (EVT3, 0.46). Although the three factors have a small gap in path values, the reasonable price exerts the most significant effect, showing that tourists attach great importance to it. Therefore, the consumption level should be managed. Moreover, it is significant to invest more resources based on the perception of the economic value of tourists. In terms of time-saving and labor-saving, although it is significant, its contribution rate is the lowest. It can be concluded that reasonable price and the value for money are the priorities to leave a good perception of economic value on tourists.

\subsection{Satisfaction and Post-Trip Behavior Intention}

The path values of the observed variables of satisfaction, including tourism expectations (TS1) and recognition (TS2) are 0.78 and 0.81 . Recognition has the greatest impact on satisfaction, followed by tourism expectations. The two factors are both significant for satisfaction. The path values of variables of post-trip behavior intention, including the willingness to revisit (RI1) and willingness to recommend (RI2) are 0.80 and 0.75 . The willingness to revisit (RI1, 0.80) is larger than willingness to recommend (RI2, 0.75); therefore, the willingness to revisit is more important in post-trip behavior intention. The tourist satisfaction and post-trip behavior intention of tourists can be improved quickly by promoting tourism expectation, recognition and the wiliness to revisit. 


\section{Discussion}

This article explores the effect of experiential value and satisfaction on post-trip behavior intentions. Experiential value contains the functional value (F1), contextual value (F2), emotional value (F3), cognitive value (F4), and economic value (F5). F1 and F2 are exogenous latent variables. The F3, F4, F5, and satisfaction (F6) are endogenous latent variables and intermediate control variables. These influencing factors directly or indirectly affect post-trip behavior intention (F7).

(1) Functional value (F1) has a direct positive impact on economic value (F5)

The above-mentioned $\mathrm{H} 1 \mathrm{~b}$ proves that functional value (F1) is positively correlated with economic value (F5) $(p<0.001)$. Figure 1 shows that the estimate from F1 to F5 is 0.22 , indicating functional value has an important impact on emotional value. Meanwhile, the above H1a and H1c are not proven, in other words, functional value does not have a direct impact on the emotional value or cognitive value ( $p=0.069,0.190$, respectively). The better functional value of MKT sites, for example, due to better ecological environment and medical service, can lead to higher tourist expenses. In particular, management strategy should focus on the perspective of protecting the ecological environment, which will be beneficial to tourists' physical health and wellness when traveling. At the same time, although the MKT destination managers can improve functional experiences by managing the ecological environment, medical service, supporting facilities, public security and activity safety, etc., so as to make tourists feel good value for money, they should strike balance between man-made supporting facilities and ecological environment protection.

(2) Contextual (F2), cognitive (F4) and economic (F5) values have direct impacts on satisfaction (F6)

$\mathrm{H} 3 \mathrm{a}, \mathrm{H} 3 \mathrm{c}$ and $\mathrm{H} 3 \mathrm{~d}$ are supported, in other words, contextual value (F2), cognitive value (F4) and economic value (F5) have direct effects on tourist satisfaction (F6) in MKT $(p<0.001)$. The estimate from F2 to F6 is -0.09 , indicating contextual value (F2) has a direct and negative influence on tourist satisfaction (F6) in MKT. Thus, maintaining natural balance and avoiding over-developed mountain surroundings are important. Moreover, the cognitive value (F4) and economic value (F5) have direct and positive impacts on tourist satisfaction (F6) in MKT, and estimates are 0.36 and 0.6. It can be seen that, compared to the cognitive value, the economic value is a more significant factor influencing tourist satisfaction. If the cognitive value (F4) and economic value (F5) are increased, the satisfaction level will be promoted. Managers of destinations should focus on the economic and cognitive experience design for tourists, such as reasonable ticket prices, encouraging tourists' experience sharing and exchanging with their companies. At the same time, tourists' participation in local cultural activities can make them acquire local cultural knowledge and customs, which can efficiently increase their satisfaction level. Hence, lower expense levels make tourists prefer to stay longer and buy some products; sharing their MKT travel experience will increase recognition; and designing local cultural activities to interact with tourists is a vital strategy component of MKT in China.

(3) Satisfaction (F6) has a significant direct and positive impact on behavior intentions (F7)

$\mathrm{H} 4$ is supported, in other words, visitor satisfaction (F6) has a direct positive influence on behavior intention (F7) in MKT $(p<0.001)$, with the estimate (F6 $\rightarrow$ F7) being 0.7 , as shown in Figure 1. The managers should make a satisfactory strategic plan for tourists, which can efficiently and directly increase the willingness to revisit and recommend. Therefore, managers can improve the tourists' expectations and recognition by rationally propagandizing the scenic area and increasing fame at the same time, which should be coordinated with landscape designer's creative ideas based on public perception of rehabilitation and physical and psychological health.

(4) Experiential value has an impact on behavior intentions (F7)

It can be seen from Figure 1 that the five dimensions of experiential values have indirect impacts on behavior intentions, and among them, economic value (F5 $\rightarrow \mathrm{F} 7,0.34)$ and 
cognitive value ( $\mathrm{F} 4 \rightarrow \mathrm{F} 7,0.25)$ are the most important positive factors indirectly influencing the willingness of tourists to revisit and recommend through satisfaction. The managers should focus on the cognitive and economic experience design for tourists, which can strengthen the willingness to engage in Kangyang tourism. For example, some adventure competition projects with lower expense but more beneficial for body health, such as mountain bike, climbing, Wushu, Tai chi, outdoor yoga and so on, can be provided for tourists to attracted them to revisit and recommend.

\section{Conclusions}

\subsection{Theoretical Contribution}

This paper is the first of its kind that investigates the relationship between MKT post-trip willingness, tourists' experiential value and tourism satisfaction. The SEM of "experiential value-satisfaction-post-trip behavior intention" is constructed. Tourist satisfaction is a mediator that significantly influences post-trip behavior intentions [73]. In the conceptual framework mentioned above, the experiential value exerts an impact on behavior intentions via the satisfaction in ecotourism and leisure tourism, etc. In the context of MKT, satisfaction also plays a significant role in mediating the influence of experience value on behavioral intention. Moreover, tourist satisfaction has also been verified to be a very important antecedent direct influencing factor of tourists' willingness to revisit and recommend. Economic value and cognitive value are vital for tourists' satisfaction level in MKT and can indirectly impact their intentions. Experiential value has an inner effect and is conceptualized with functional value, contextual value, emotional value, cognitive value and economic value. The functional value has a direct positive effect on the economic value in MKT. Economic value is the key to achieving high experiential quality in destinations, especially the reasonable price, good value for money and time-saving and labor-saving of the journal to increase the satisfaction level in MKT. In addition, visitors are likely to form perceptions that originate from cognition, which will affect their behavior intentions, but intentions are not immediately determined by the cognition of culture, knowledge and competition activities. It can be concluded that satisfaction plays an important role in mediating the relationship between cognition and behavioral consequences [73].

\subsection{Managerial Implications}

This paper is the first to develop and empirically examine a conceptual model of the experience value, satisfaction and post-trip behavior intentions of a traveler to revisit and recommend an MKT destination after an MKT trip. It is suggested that MKT destination managers should focus on these aspects when they plan and design destinations. Firstly, it is beneficial for managers to enhance tourists' satisfaction and plan by rationally propagandizing the scenic area and enhances the fame of the MKT destination to enhance people's willingness to revisit and recommend, so that more people will join Kangyang activities and increase the competitive advantage of the MKT destinations. Secondly, MKT destination operators should consider the economic experiences among visitors, governments and non-profit organizations to promote MKT, such as control the product price, more convenient transportation and infrastructures to save money and labor, and no scenic tickets for destinations, so that tourists will spend more money on cultural health and wellness activities or projects and long-time staying accommodation, etc. Thirdly, MKT managers can leave a good impression on tourists by allocating more construction resources to ecological and environmental protection and medical service to heal tourists' bodies. The strategies for MKT destinations should be functional, comprehensive, ecological and rational, and avoid excessive development so that the contextual environment can conform to tourists' physical and psychological health conditions. The last, focusing on the development of projects that increase the cognitive value of tourists, such as mountain bike competitions, outdoor yoga and other cultural participatory interactions, will increase tourists' interest in the experience, which will inevitably satisfy them. 
It addresses the complexities of sustainable tourism management by studying the interrelationships between various factors, including tourists' experiential value (functional value, contextual value, cognitive value, emotional value and economic value), satisfaction and willingness to revisit and recommend in MTK after their visits. As the local government strives to make the MKT destination a world-class tourism destination, more parties are expected to be involved in constructing the ecological, quality and sustainable environments, such as upper-level governments, external investors, migrant service workers and landscape designers as well as more settings such as highways, high-quality healthcare facilities and ecological environment.

\section{Limitations}

This research studies the relationship among experiential value, satisfaction and posttrip willingness to revisit and recommend from the perspective of tourist value perception. The relationship between value perceptions is complex, while it is willingness to do something positively impact actual behavior [89], such relationship is unknown in MKT. As such further study may be conducted in the future Moreover, only data of visitors in Panzhihua City, an MKT destination in China, were collected. Whether the results can be applied to tourists from other MKT destinations in different regions of China or other mountain-based countries has yet to be further studied.

Author Contributions: Conceptualization, L.Z.; methodology, L.Z. and R.Y.M.L.; software, L.Z.; validation, L.Z. and R.Y.M.L.; formal analysis, L.Z.; investigation, L.Z.; resources, L.Z.; data curation, L.Z.; writing-original draft preparation, L.Z.; writing—review and editing, L.Z. and R.Y.M.L.; visualization, L.Z.; supervision, R.Y.M.L.; project administration, L.Z. and R.Y.M.L.; funding acquisition, L.Z. All authors have read and agreed to the published version of the manuscript.

Funding: This research was funded by the Ph.D. Starting Research Fund from the Panzhihua University. [No. 035200153].

Institutional Review Board Statement: The study was approved by the Ethics Committee (HREC), Hong Kong Shue Yan University (Reference No. HREC 21-02 (4) and date of approval is 11 March 2021.

Informed Consent Statement: Informed consent was obtained from all subjects involved in the study. Data Availability Statement: Not applicable.

Conflicts of Interest: The authors declare no conflict of interest.

\section{References}

1. Zhang, Y.; Lin, Z.; Lee, T. Wellness-oriented seasonal tourism migration: A field relationship study in China. Int. J. Tour. Res. 2020, 23, 491-503. [CrossRef]

2. Bushueva, I. Trends of Wellness Tourism Development in Russia. Tur. Estud. Práticas 2020, 4, 38.

3. Lehto, X.; Lehto, M. Vacation as a Public Health Resource: Toward a Wellness- Centered Tourism Design Approach. J. Hosp. Tour. Res. 2019, 43, 935-960. [CrossRef]

4. Gossling, S.; Scott, D.; Hall, C. Pandemics, tourism and global change: A rapid assessment of COVID-19. J. Sustain. Tour. 2021, 29, 1-20. [CrossRef]

5. UNWTO. The Impact of COVID-19 on International Tourism; UNWTO: Madrid, Spain, 2020.

6. Yang, F.; Wong, I. The social crisis aftermath: Tourist well-being during the COVID-19 outbreak. J. Sustain. Tour. 2020, 29, 859-878. [CrossRef]

7. Cao, X. COVID-19: Immunopathology and its implications for therapy. Nat. Rev. Immunol. 2020, 20, 269-270. [CrossRef]

8. Alexis, C. An examination of issues related to tourism and health and well-being as a sustainable development goal by tourism providers in Tobago. Worldw. Hosp. Tour. Themes 2020, 12, 293-303. [CrossRef]

9. Lee, T.J.; Han, J.-S.; Ko, T.-G. Health-Oriented Tourists and Sustainable Domestic Tourism. Sustainability 2020, 12, 4988. [CrossRef]

10. Xiong, Y.; Zhang, Y.; Lee, T.J. The rural creative class: An analysis of in-migration tourism entrepreneurship. Int. J. Tour. Res. 2020, 22, 42-53. [CrossRef]

11. Pan, X.; Yang, Z.; Han, F.; Lu, Y.; Liu, Q. Evaluating Potential Areas for Mountain Wellness Tourism: A Case Study of Ili, Xinjiang Province. Sustainability 2019, 11, 5668. [CrossRef]

12. Qiu, M.; Sha, J.; Scott, N. Restoration of Visitors through Nature-Based Tourism: A Systematic Review, Conceptual Framework, and Future Research Directions. Int. J. Environ. Res. Public Health 2021, 18, 2299. [CrossRef] 
13. Yeon, J.; Hwa, K.; Timothy, J. Visitor Motivational Factors and Level of Satisfaction in Wellness Tourism:Comparison between First-Time Visitors and Repeat Visitors. Asia Pac. J. Tour. Res. 2015, 21, 137-156. [CrossRef]

14. Yan, X.; He, S. The co-evolution of therapeutic landscape and health tourism in bama longevity villages, China: An actor-network perspective. Health Place 2020, 66, 102448. [CrossRef]

15. Smith, M.; Puczk, L. Health and Wellness Tourism; Elsevier: Amsterdam, The Netherlands, 2009.

16. Shablii, O.; Zastavetska, L.; Dudarchuk, K.; Illiash, I.; Smochko, N. The main problems of healthcare and wellness tourism in Ukraine. J. Geol. Geogr. Geoecol. 2018, 27, 337-345. [CrossRef]

17. Vincent, C.; Deniz, K. Wellness Tourism in China: Resources, Development and Marketing. Int. J. Tour. Res. 2013, 15, 346-359. [CrossRef]

18. Hall, C.M. Health and medical tourism: A kill or cure for global public health? Tour. Rev. 2011, 66, 4-15. [CrossRef]

19. Hoheb, C. Wellness Tourism; Lowry, L.L., Ed.; Sage: Thousand Oaks, CA, USA, 2017.

20. Hritz, N.M.; Sidman, C.L.; D’Abundo, M. Segmenting the College Educated Generation Y Health and Wellness Traveler. J. Travel Tour. Mark. 2014, 31, 132-145. [CrossRef]

21. Smith, M.; Kelly, C. Wellness tourism. Tour. Recreat. Res. 2006, 31, 1-4. [CrossRef]

22. Kazakov, S.; Oyner, O. Wellness tourism: A perspective article. Tour. Rev. 2021, 76, 58-63. [CrossRef]

23. Voigt, C. Wellness Tourism: A Destination Perspective; Pforr, C., Ed.; Routledge: Oxford, UK, 2013.

24. Hartwell, H.; Fyall, A.; Willis, C.; Page, S.; Ladkin, A.; Hemingway, A. Progress in tourism and destination wellbeing research. Curr. Issues Tour. 2018, 21, 1830-1892. [CrossRef]

25. Cheng, L.; Zhang, L. Religious Cultural Heritage Tourism Impacts on Tourists: A Case Study of Taosim Tourism in the Wudang Mountain of China. Sci. Geogr. Sin. 2017, 37, 1569-1576. [CrossRef]

26. Pessot, E.; Spoladore, D.; Zangiacomi, A.; Sacco, M. Natural Resources in Health Tourism: A Systematic Literature Review. Sustainability 2021, 13, 2661. [CrossRef]

27. Endler, C.; Matzarakis, A. Climate and tourism in the Black Forest during the warm season. Int. J. Biometeorol. 2011, 55, 173-186. [CrossRef]

28. Yang, S.U.N. Study on Development of Wellness Tourism Resource for Chang-Ji-Tu Region. In Proceedings of the 3rd International Conference on Social Science and Management (ICSSM 2017), Xi'an, China, 8-9 April 2017; pp. 180-183.

29. Bae, J.-H.; Lee, S.-H.; Lee, J.-M.; Kim, S.-M. The Effect of Place Attachment on Visit Satisfaction and Behavioral Intention in Mountain Village. J. Hotel Resort 2019, 18, 245-264.

30. Jeong, G.Y. A Study on Survey and Analysis of Landscape Plans for Improving the Quality of Life in Rural Areas -Focus on Byeongyeong-myeon, Gangjin-gun, Jeollanam-do. J. Digit. Converg. 2020, 18, 133-138. [CrossRef]

31. Choi J.H., C.; Kim, C. The effect of wellness tourism selection attributes on visitors' satisfaction and intention to revisit. J. Hosp. Tour. Stud. 2021, 23, 43-57. [CrossRef]

32. Kim, C.W.; Jaehyung, L. The Effect of the Satisfactory on Re-Participation Intention and Conversion Intention of the Sports Tourism Participant. Korea Sport Res. 2004, 15, 853-864.

33. Kim, J. A study on Tourist Satisfaction and Revisit Intension in Culture Tourism Festival- Focusing on Korea Traditional Chassabal Festival 2005. J. Hosp. Tour. Stud. 2005, 7, 95-114.

34. Noh, Y. Assessment of Expectation and Performance of Service Quality by Type of Experience Tourism Village. J. Korean Data Anal. Soc. 2006, 8, 2507-2520.

35. Hyun-Sik, J. The Effects of Medical Esthetic Tourism Service Quality on Customer Trust, Satisfaction, Commitment and Reuse Intention. J. Hosp. Tour. Stud. 2008, 10, 180-199.

36. Williams, P.; Soutar, G.N. Value, Satisfaction and Behavioral Intentions in an Adventure Tourism Context. Ann. Tour. Res. 2009, 36, 413-438. [CrossRef]

37. Loncaric, D.; Prodan, M.P.; Bagaric, L. The Relationship between Tourism Experience Co-Creation, Life Satisfaction and Behavioural Intentions. Cent. Eur. Bus. Rev. 2018, 7, 1-14. [CrossRef]

38. Li, T.; Liu, F.; Soutar, G. Experiences, post-trip destination image, satisfaction and loyalty: A study in an ecotourism context. J. Destin. Mark. Manag. 2021, 19, 100547. [CrossRef]

39. Rasoolimanesh, S.M.; Seyfi, S.; Rather, R.; Hall, C. Investigating the mediating role of visitor satisfaction in the relationship between memorable tourism experiences and behavioral intentions in heritage tourism context. Tour. Rev. 2021, 76, 1-23. [CrossRef]

40. Rahman, M.S.; Bag, S.; Hassan, H.; Hossain, M.A.; Singh, R.K. Destination brand equity and tourist's revisit intention towards health tourism: An empirical study. Benchmarking Int. J. 2021. [CrossRef]

41. Han, S.; Yoon, J.H.; Kwon, J. Impact of Experiential Value of Augmented Reality: The Context of Heritage Tourism. Sustainability 2021, 13, 4147. [CrossRef]

42. Lebrun, A.M.; Su, C.J.; Bouchet, P. A More Sustainable Management of Domestic Tourists in Protected Natural Parks: A New Trend in Sport Tourism after the COVID-19 Pandemic? Sustainability 2021, 13, 7750. [CrossRef]

43. Damanik, J.; Yusuf, M. Effects of perceived value, expectation, visitor management, and visitor satisfaction on revisit intention to Borobudur Temple, Indonesia. J. Herit. Tour. 2021, 10, 1-16. [CrossRef]

44. Jamal, S.A.; Muhammad, N.M.N. Visitor perceived value in a community-based homestay visit: An investigation into the functional and experiential aspect of value. J. Vacat. Mark. 2011, 17, 5-15. [CrossRef] 
45. Lee, S.; Phau, I.; Hughes, M.; Li, Y.F.; Quintal, V. Heritage tourism in Singapore Chinatown: A perceived value approach to authenticity and satisfaction. J. Travel Tour. Mark. 2016, 33, 981-998. [CrossRef]

46. Choe, J.Y.; Kim, S. Effects of tourists' local food consumption value on attitude, food destination image, and behavioral intention. Int. J. Hosp. Manag. 2018, 71, 1-10. [CrossRef]

47. Lee, T.-C.; Peng, M.Y.-P. Green Experiential Marketing, Experiential Value, Relationship Quality, and Customer Loyalty in Environmental Leisure Farm. Front. Environ. Sci. 2021, 9, 657523. [CrossRef]

48. Baker, J.; Parasuraman, A.; Grewal, D.; Voss, G.B. The influence of multiple store environment cues on perceived merchandise value and patronage intentions. J. Marking 2002, 66, 120-141. [CrossRef]

49. Brun, I.; Rajaobelina, L.; Ricard, L.; Berthiaume, B. Impact of customer experience on loyalty: A multichannel examination. Serv. Ind. J. 2017, 37, 317-340. [CrossRef]

50. Tsai, C.T.S.; Wang, Y.C. Experiential value in branding food tourism. J. Destin. Mark. Manag. 2017, 6, 56-65. [CrossRef]

51. Chen, Y.; Chen, R.; Hou, J.; Hou, M.; Xie, X. Research on users' participation mechanisms in virtual tourism communities by Bayesian network. Knowl. Based Syst. 2021, 226, 107161. [CrossRef]

52. Jiang, Y.; Hong, F. Examining the relationship between customer-perceived value of night-time tourism and destination attachment among Generation Z tourists in China. Tour. Recreat. Res. 2021, 41, 1-14. [CrossRef]

53. Chang, W.; Huang, L. Measuring service experience: A utility-based heuristic model. Serv. Bus. 2016, 10, 1-30. [CrossRef]

54. Els, D.A.; de La Rey, R.P. Developing a holistic wellness model. SA J. Hum. Resour. Manag. 2006, 4, 46-56. [CrossRef]

55. Wu, G.; Zheng, X. Study on the development model of wellness tourism in China. Health Care Today 2017, 3, $294-298$.

56. Vila, N.A.; Brea, J.A.F.; de Araújo, A.F. Health and Sport. Economic and Social Impact of Active Tourism. Investig. Health Psychol. Educ. 2020, 10, 70-81. [CrossRef] [PubMed]

57. Lei, S.; Wang, D.; Law, R. Mobile-based value co-creation: Contextual factors towards customer experiences. Tour. Rev. 2021. [CrossRef]

58. Tsai, H. Individual-level absorptive capacity and multidimensional work behavior in tourism. J. Organ. Chang. Manag. 2021. [CrossRef]

59. Zins, A. Centrality of Recreation Activities; Weiermair, K., Pechlaner, H., Bieger, T., Eds.; ESV: Berlin, Germany, 2006.

60. Buckley, R. Adventure Tourism Management; Routledge: Oxford, UK, 2011.

61. Moon, S.; Choi, M. Health Administration, 4th ed.; Bomungak: Seoul, Korea, 2011.

62. Xu, F.; Tan, J.; Lu, L.; Li, S.; Qin, L. How Does Value Co-Creation Behavior Affect Destination Loyalty? A Role Switching Perspective. J. Theor. Appl. Electron. Commer. Res. 2021, 16, 101. [CrossRef]

63. Nam, K. Management Plan of Jeju Oreum through an Analysis on Wellness Travel Motivations. J. Mice Tour. Res. 2021, 21, 55-75. [CrossRef]

64. Lee, C.; Reisinger, Y.; Ahmad, M.; Park, Y.; Kang, C. The influence of Hanok experience on tourists' attitude and behavioral intention: An interplay between experiences and a Value-Attitude-Behavior model. J. Vacat. Mark. 2021, $27,13567667211011761$. [CrossRef]

65. Wang, K.; Xu, H.; Huang, L. Wellness tourism and spatial stigma: A case study of Bama, China. Tour. Manag. 2020, 78, 104039. [CrossRef]

66. Goncalves, E.; Guerra, R. Health and wellness tourism as a local development factor: An analysis of the Portuguese thermal and mineral springs. Pasos Rev. Tur. Patrim. Cult. 2019, 17, 453-472. [CrossRef]

67. Salazar, N.B.; Zhang, Y. Seasonal lifestyle tourism: The case of Chinese elites. Ann. Tour. Res. 2013, 43, 81-99. [CrossRef]

68. Shin, H.; Jeong, M. Travelers' motivations to adopt augmented reality (AR) applications in a tourism destination. J. Hosp. Tour. Technol. 2021, 12, 389-405. [CrossRef]

69. Krivosheeva, T. Tourism and Local Lore Activities as a Farm of Studying the Local Socio-Colturai Environment. Laplage Em Rev. 2021, 7, 94-102. [CrossRef]

70. Niko, K. Wellness: A New Mode of tourism. Econ. Res. Ekon. Istraž. 2012, 25, 525-534. [CrossRef]

71. Han, J.-S.; Lee, T.J.; Ryu, K. The promotion of health tourism products for domestic tourists. Int. J. Tour. Res. 2018, 20, 137-146. [CrossRef]

72. Carvache-Franco, M.; Pérez-Orozco, A.; Carvache-Franco, W.; Víquez-Paniagua, A.G.; Carvache-Franco, O. Motivations and their influence on satisfaction and loyalty in eco-tourism: A study of the foreign tourist in Costa Rica. Anatolia Int. J. Tour. Hosp. Res. 2021, 98, 1-16. [CrossRef]

73. Kim, B.; Chen, Y. The effects of spirituality on visitor behavior: A cognitive-affective-conative model the effects of spirituality on visitor behavior. Int. J. Tour. Res. 2021, 23, 1-12. [CrossRef]

74. Qian, L.; Zhang, J.; Zhang, H.; Zheng, C. Hit close to home: The moderating effects of past experiences on tourists' on-site experiences and behavioral intention in post earthquake site. Asia Pac. J. Tour. Res. 2017, 22, 936-950. [CrossRef]

75. Prayag, G.; Hosany, S.; Muskat, B.; del Chiappa, G. Understanding the relationships between tourists' emotional experiences, perceived overall image, satisfaction, and intention to recommend. J. Travel Res. 2017, 56, 41-54. [CrossRef]

76. Tan, W.K. Repeat visitation: A study from the perspective of leisure constraint, tourist experience, destination images, and experiential familiarity. J. Destin. Mark. Manag. 2017, 6, 233-242. [CrossRef]

77. Oriade, A.; Schofield, P. An examination of the role of service quality and perceived value in visitor attraction experience. $J$. Destin. Mark. Manag. 2019, 11,1-9. [CrossRef] 
78. Jensen, Ø.; Li, Y.; Uysal, M. Visitors' satisfaction at managed tourist attractions in Northern Norway: Do on-site factors matter? Tour. Manag. 2017, 63, 277-286. [CrossRef]

79. Chen, C.-F.; Chen, F.-S. Experience quality, perceived value, satisfaction and behavioral intentions for heritage tourists. Tour. Manag. 2010, 31, 29-35. [CrossRef]

80. Jang, S.; Feng, R. Temporal destination revisit intention: The effects of novelty seeking and satisfaction. Tour. Manag. 2007, 28, 580-590. [CrossRef]

81. Petrick, J.F.; Backman, S.J. An examination of the determinants of golf travelers' satisfaction. J. Travel Res. 2002, 40, 252-258. [CrossRef]

82. Bajs, I.P. Tourist perceived value, relationship to satisfaction, and behavioral intentions: The example of the Croatian tourist destination Dubrovnik. J. Travel Res. 2015, 54, 122-134. [CrossRef]

83. Assaker, G.; Vinzi, V.E.; O'Connor, P. Examining the effect of novelty seeking, satisfaction, and destination image on tourists' return pattern: A two factor, nonlinear latent growth model. Tour. Manag. 2011, 32, 890-901. [CrossRef]

84. Lee, W.; Jeong, C. Distinctive roles of tourist eudaimonic and hedonic experiences on satisfaction and place attachment: Combined use of SEM and necessary condition analysis. J. Hosp. Tour. Manag. 2021, 47, 58-71. [CrossRef]

85. Read, D. Experienced utility: Utility theory from Jeremy Bentham to Daniel Kahneman. Think. Reason. 2007, 13, 45-61. [CrossRef]

86. Chua, B.-L.; Lee, S.; Goh, B.; Han, H. Impacts of cruise service quality and price on vacationers' cruise experience: Moderating role of price sensitivity. Int. J. Hosp. Manag. 2015, 44, 131-145. [CrossRef]

87. Mueller, H.; Kaufmann, E.L. Wellness tourism: Market analysis of a special health tourism segment and implications for the hotel industry. J. Vacat. Mark. 2001, 7, 5-17. [CrossRef]

88. Catarina, M.; Rui, V.S.; Stanislava, A. Image, satisfaction, destination and product post-visit behaviours: How do they relate in emerging destinations? Tour. Manag. 2021, 85, 104293. [CrossRef]

89. Li, R.Y.M.; Tang, B.; Chau, K.W. Sustainable Construction Safety Knowledge Sharing: A Partial Least Square-Structural Equation Modeling and A Feedforward Neural Network Approach. Sustainability 2019, 11, 5831. [CrossRef] 